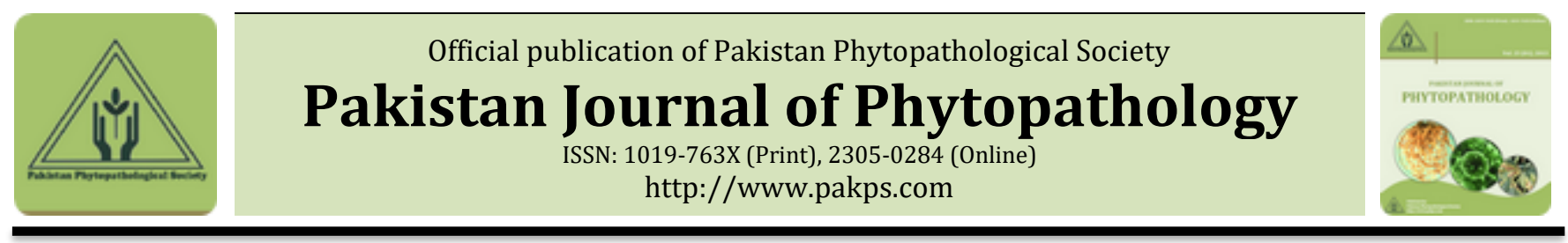

\title{
INTERACTION OF CITRUS CANKER WITH PHYLLOCNISTIS CITRELLA STAINTON
}

\author{
Amna Riasat, Muhammad U. Ghazanfar, Waqas Raza \\ Department of Plant Pathology, College of Agriculture, University of Sargodha, 40100 Pakistan.
}

A B S T R A C T

Present investigations deal with the co-relation of inoculation methods and citrus leafminer (Phyllocnistis citrella Stainton) development stages with Citrus canker disease incidence on citrus seedlings. Bacterial pathogen was applied at three different concentrations i.e. $1 \times 10^{2}, 1 \times 10^{4}$ and $1 \times 10^{6} \mathrm{cfu} \mathrm{ml}{ }^{-1}$ and effect was monitored after $4,8,12$, 16- and 20-days post treatment. Seven discrete treatments were compared: intact leaves, mechanically wounded leaves, CLM injured leaves (egg, first instar larvae, second instar larvae, third instar larvae and pupal stage). Results revealed that injuries caused by $3^{\text {rd }}$ instar larvae (TIL) and pupal stage (PS) lead to maximum disease incidence .The maximum disease incidence in case of TIL was 50.61, 68.51, 81.47, 93.20, and $100 \%$ whereas, for PS it was 43.82 , 59.25, 71.60, 84.56 and $100 \%$ after 4, 8, 12, 16 and 20 days at the highest dose rate. It was concluded that for establishing an effective plant protection program attention should be necessarily given to the ecology of pest species considering the emerging threats of the insect pests and pathogens to horticultural and other food crops of the country.

Keywords: Citrus, Leafminer, Citrus Canker, Damage, Management

\section{INTRODUCTION}

The versatile climatic conditions of Pakistan are quite suitable for the growth of variety of fruits, among them citrus is one of the most profitable and highly productive fruit crops (Urbaneja et al., 2003). Citrus is an important fruit crop grown in subtropical and tropical regions of the world (Sharif et al., 2009). It holds a significant position among the fruits, contributing about $40 \%$ of country's total fruit production (Urbaneja et al., 2003; Liu et al., 2012). Pakistan is recognized as 6th largest grower of oranges (https://www.arabnews.pk/ node/1435906/pakistan) of citrus. However, the yield of citrus is low as compared to other developed countries due to the adverse effects of several biotic and abiotic factors (Urbaneja et al., 2003).

Among biotic factors, the disease "citrus canker" caused by the bacterium Xanthomonas axonopodis, the infection

\begin{tabular}{l} 
Submitted: December 27, 2018 \\
Revised: May 05, 2020 \\
Accepted for Publication: June 06, 2020 \\
* Corresponding Author: \\
Email: usmanghazanfar1073@yahoo.com \\
(C) 2017 Pak. J. Phytopathol. All rights reserved. \\
\hline
\end{tabular}

results lesions on the leaves, stems and fruits of citrus trees, including lime, oranges and grape fruit. The disease is found to have a very strong relationship with citrus leafminer, Phyllocnistis citrella, Stainton (Lepidoptera: Gracillaridae) (Chagas et al., 2001). The larvae of CLM are tiny, greenish-yellow, translucent and usually found in the leaf mines. Pupae are normally enclosed in pupal cases at leaf margin (De Prins et al, 2005).The females lay their eggs on freshly emerged leaves near veins or midrib, mostly preferred the lower surface of leaf. Though both mines and eggs can be found on lower and upper surface of leaf (Ba-Angood, 1977) Once disease is established defoliation, premature fruit dropping, blemished fruits, tree decline and twig dieback occurs (Diez et al., 2006). Though $P$. citrella is not a vector of citrus canker but larvae feeding on leaves provide entry point to pathogen which ultimately results the onset of bacterial canker disease (Belasque et al., 2005). After being entered, bacteria propagate in lesions on stem, leaves and fruits. Due to free moisture in lesions these bacteria ooze out and spread to new host plants. Wind-driven rain, rainwater and wind speed are main dispersal agent and 
help in bacterial penetration via stomatal pores or wounds made by insects, thorns and blowing sand (Timmer, 2000). Pruning also causes wounding which can be primary site for pathogen infection (Gottwald et al., 2001). Economic losses occur due to presence of citrus leafminers including increase in insecticide cost for protecting young trees and seedlings. A number of studies have been directed to correlate CLM damage with economic losses (Pena, et al., 2000).

However few studies are available investigating the correlation between CLM and disease incidence. Gottwald et al., (1997) reported that the feeding activities of $P$. citrella facilitate the Xac. infections and large amounts of bacterial inoculum produced in this way is spread by rain splash. Various field surveys conducted in different countries showed increased levels of citrus canker infestation up to $75 \%$ in citrus leaves in simultaneous presence of CLM (Heppner, 1993). Graham et al., (1996) stated that when the larvae mine through the leaves it provides passage for bacterial cells along the galleries within leaves. While investigating a relationship between different levels of the lesion caused by the CLM and the degree of infection by Xac in citrus plants, Chagas et al. (2001) found a close correlation between CLM infestation and bacterium infestation irrelevant of the conditions under which experimental trails were performed.

This is an established fact that globally the disease Asiatic citrus canker is abundantly found where plenty of rain and high temperatures simultaneously exist (Pruvost et al. 1997), and there is an increased damage potential of this insect in warmer regions. Keeping in view the significant role of Citrus in Pakistan's agriculture and economy, and lack of local data available regarding the due role of CLM in the spread of citrus canker present study was designed. The objectives of this study are to investigate the interaction of citrus canker disease not only with different inoculation methods but the relation was also examined with reference to different developmental stages of citrus leaf miner.

\section{MATERIALS AND METHODS}

The research work was conducted in laboratory of Plant Pathology, College of Agriculture, University of Sargodha, Punjab, Pakistan during 2017-18 to study interaction of citrus canker with citrus leafminer.

Isolation of bacterial culture and identification: Infected samples were collected from the field area of
College of Agriculture, University of Sargodha $\left(32 \circ 5^{\prime} 1^{\prime \prime} \mathrm{N} 72^{\circ} 40^{\prime} 16^{\prime \prime} \mathrm{E}\right)$. Infected citrus leaves with canker were taken and infected portion of leaves were cut into small pieces of diameter 2-3 $\mathrm{mm}$ approximately. Infected pieces of leaves were surface sterilized with $1 \%$ solution of sodium hypochlorite for 3-4 minutes and rinsed 2-3 times with distilled water. Disinfected cuts were dried after placing them on the sterilized filter paper. With the help of sterilized forceps these pieces were placed in the petri plates containing nutrient agar solidified media. Petri plates were wrapped with Parafilm tape and placed in incubator under controlled conditions $\left(25 \pm 5^{\circ} \mathrm{C}\right.$ and 60 $\pm 10 \%$ of R.H) for one week.

The bacterium was identified on the bases of its cultural and morphological characters i.e. the shape, color size, pattern, elevation and appearance of the culture as suggested in the Guide to Plant Pathogenic Bacteria (Braduery,1986) and Laboratory Guide for the Identification of the Plant Pathogenic Bacteria (Sohi et al., 1968).

Bacterial suspension preparation: The plate count method was used for the preparation of the bacterial culture. In this regards, $1 \mathrm{~mL}$ of the fresh bacterial culture was taken to mix with $9 \mathrm{ml}$ of distilled water. Serial dilution method was used upto 6-8 folds to get the required concentration to be used in the bioassays.

Raising of sweet orange seedlings: Sweet orange seedlings $(25-30 \mathrm{~cm}$ tall) were transplanted into the potted cups containing soil and well rotten FYM with ratio $2: 1$. The seedlings were pruned and were kept under semi-natural conditions of green house for next 15-20 days till flushing (Chagas et al., 2001). Meanwhile, the transplanted plant received all recommended practices (fertilizer application, weeding) and irrigations till the inoculation with the bacterial and fungal cultures.

Rearing of citrus leafminer: Seedlings raised through the above mentioned method were introduced to citrus leafminer larvae obtained from laboratory culture. Different groups of seedling placed in net cages were used for this purpose to introduce with CLM at one week interval. After 3 weeks, adult leafminers were emerged and allowed to mate for egg laying, thus artificial reinfestation was not needed. The adults were provided with a mixture of honey and water at the ratio of $1: 3(\mathrm{v} / \mathrm{v})$ sprayed on plants. After taking several generations by introducing new plant after each cycle, 
we were able to get enough CLM population to proceed towards our experiment.

Inoculation of plants: A set of 63 potted cups were taken that contained 9 healthy seedlings as control treatment seedlings and 54 test seedlings were punctured with sterilized syringes to achieve mechanical injury on fresh leaves. The bacterial suspension at the concentration of $1 \times 10^{2}, 1 \times 10^{4}$ and $1 \times 10^{6} \mathrm{CFU} / \mathrm{mL}$ was sprayed on the wounded seedlings to facilitate the entry of the bacterial spores. In order to represent the intact leaf inoculation, a separate set of experiment was prepared where a set of 63 potted cups were taken in which the 9 healthy seedlings were sprayed with the distilled water only and 54 seedlings were sprayed each with bacterial suspension at the concentration of $1 \times 10^{2}, 1 \times 10^{4}$ and $1 \times 10^{6} \mathrm{CFU} / \mathrm{mL}$ and these cups were covered with net cage. To maintain the relative humidity wet cotton was placed in the net cage. Moisture level was maintained with continuous spray. Disease incidence was observed by sampling the seedlings (three leaves collected from each plant $=27$ plants per treatment) and recorded at $4,8,12,16$ and 20 days of post application using the following formula suggested by Waller et al. (2002) with some modifications. Each treatment was consisted of nine seedlings and each treatment had six replicates.

$$
\text { Disease incidence } \%=\frac{\text { No. of infected plants }}{\text { Total number of plants }} \times 100
$$

Interaction of life stages of CLM with disease occurrence: Citrus leafminer infected plants were attained by placing them into egg laying chamber of leafminer with the protocol used by jesus and Parra (2000). The infested plants were removed at egg stage, $1^{\text {st }}$ instar stage, $2^{\text {nd }}$ instar stage, $3^{\text {rd }}$ instar stage and pupal stage. Citrus leafminer injured plant leaves were inoculated with bacterial suspension at concentration of $1 \times 10^{2}, 1 \times 10^{4}$ and $1 \times 10^{6} \mathrm{CFU}$ per mL. Control treatment was received only distilled water. Data for disease incidence was recorded from sampled plants (three leaves collected from each plant $=27$ plants per treatment) at $4,8,12,16$ and 20 days of post application. Each treatment was consisted of nine seedlings and each treatment has six replicates.

\section{STATISTICAL ANALYSIS}

Data was statistically analyzed by using analysis of variance (ANOVA) in Statistics and means were compared by using Tukey test at $5 \%$ significant level (Sokal and Rohlf, 1995).

\section{RESULTS}

Correlation between CLM stages and disease incidence at different intervals: All the treatments that were tested caused the citrus canker except control plants that only received distilled water. The disease incidence was found to be directly proportional to concentrations, as incidence increased with increasing concentration. At 4 days interval, only the treatment third instar larvae of CLM (TIL) caused 50\% disease incidence at maximum concentration $1 \times 10^{6}$ $\mathrm{CFU} / \mathrm{ml}$. At 4 days interval, maximum and minimum incidence was observed as (14.81\%, 35.79\%, 50.61\%) and $(0.00 \%, 0.00 \%, 2.46 \%)$ against $1 \times 10^{2}, 1 \times 10^{4}$ and $1 \times 10^{6} \mathrm{CFU} / \mathrm{ml}$ respectively. Four day after post inoculation, against maximum concentration $1 \times 10^{6}$ $\mathrm{CFU} / \mathrm{mL}$ The highest disease incidence observed in case of TIL (50.61\%), was followed by PS (43.82\%), SIL (32.09\%), MI (14.18\%), ES (8.63\%), FIL (4.31\%) and IL $(4.31 \%)$ (Table 1$)$. At 8 days interval, again the treatment third instar larvae of CLM (TIL) was the most effective treatment causing $>50 \%$ disease incidence at $1 \times 10^{6} \mathrm{CFU} / \mathrm{ml}$. At 8 days interval, maximum $(32.71 \%$, $49.37 \%, 68.51 \%)$ and minimum $(0.00 \%, 5.55 \%, 9.25 \%)$ incidence was noted at $1 \times 10^{2}, 1 \times 10^{4}$ and $1 \times 10^{6}$ $\mathrm{CFU} / \mathrm{mL}$, respectively. At 8 days of post inoculation, the highest disease incidence observed in case of TIL (68.51\%) was followed by PS (59.25\%), SIL (53.69\%), MI (27.77\%), ES (26.53\%), FIL (23.34\%) and IL (9.25\%) (Table 2). After 12 days of treatment, third instar larvae of CLM (TIL) caused $>80 \%$ disease incidence at $1 \times 10^{6} \mathrm{CFU} / \mathrm{mL}$. The maximum $(43.81 \%$, $64.81 \%, 81.47 \%)$ and minimum (1.85\%, 7.40\%, $15.42 \%$ ) incidence was observed against $1 \times 10^{2}, 1 \times 10^{4}$ and $1 \times 10^{6} \mathrm{CFU} / \mathrm{mL}$ of dose rates, respectively. At the same interval, the highest disease incidence observed in case of TIL (81.47\%), followed by PS (71.60\%), SIL (62.34\%), ES (41.35\%), MI (35.79\%), FIL (31.47\%) and IL $(15.42 \%)$ at $1 \times 10^{6} \mathrm{CFU} / \mathrm{mL}$ (Table3). At 16 day interval, treatment third instar larvae of CLM (TIL) caused $>90 \%$ disease incidence at maximum concentration $1 \times 10^{6} \mathrm{CFU} / \mathrm{mL}$. Here, the maximum and minimum incidence observed (61.72\%, 85.18\%, $93.20 \%)$ and $(5.55 \%, 13.57 \%, 18.51 \%)$ against $1 \times 10^{2}$, $1 \times 10^{4}$ and $1 \times 10^{6} \mathrm{CFU} / \mathrm{mL}$, respectively. Sixteen days post inoculation, at $1 \times 10^{6} \mathrm{CFU} / \mathrm{mL}$, the highest disease incidence observed in case of TIL (93.20\%), followed by PS (84.56\%), SIL (78.39\%), ES (48.14\%), MI (41.97\%), FIL (40.73\%) and IL (18.51\%) (Table 4). At 
20 days interval, the treatments TIL and PS caused 100 $\%$ disease incidence at maximum concentration $1 \times 10^{6}$ $\mathrm{CFU} / \mathrm{mL}$. At 20 days interval, the maximum and minimum incidence observed $(70.36 \%, 92.58 \%, 100 \%)$ and $(8.01 \%, 17.27 \%, 24.69 \%)$ against $1 \times 10^{2}, 1 \times 10^{4}$ and $1 \times 10^{6} \mathrm{CFU} / \mathrm{mL}$, respectively. Twenty day after inoculation, against maximum concentration $1 \times 10^{6}$ $\mathrm{CFU} / \mathrm{mL}$, the highest disease incidence observed in case of TIL and PS (100\%), followed by SIL (94.45\%), ES (55.56\%), MI (53.70\%), FIL (47.53\%) and IL (24.69\%) (Table 5).

Table1. Effect of different concentrations of Xanthomonas axanopodis via different method of inoculation (Intact leave

Effect of inoculation methods on disease incidence:

As described earlier, two inoculation methods i.e. Intact leaf (IL) and Mechanical Injury (MI) were used to introduce bacterium into citrus seedlings. Results exhibited that MI was more effective inoculation method than IL on all test dose rates with maximum incidence rate of $53.70 \%$ at $1 \times 10^{6} \mathrm{CFU} / \mathrm{mL}$ after 20 days of treatment (Tables 1-5). While, on the other hand, the maximum incidence rate for IL method was only $24.69 \%$ even after 20 days of treatment application (Table 5)

(IL), Mechanical Injury (MI), Egg Stage (ES), $1^{\text {st }}$ instar larvae (FIL), $2^{\text {nd }}$ instar larvae (SIL), $3^{\text {rd }}$ Instar larvae

(TIL), and pupal stage (PS) on disease incidence (\%) of citrus canker at 4 day interval

\begin{tabular}{cccc}
\hline Stage & $1 \times 10^{2}$ & $1 \times 10^{4}$ & $1 \times 10^{6}$ \\
\hline IL & $0.00 \pm 0.00 \mathrm{c}$ & $1.23 \pm 0.78 \mathrm{e}$ & $4.31 \pm 1.13 \mathrm{ef}$ \\
\hline MI & $0.00 \pm 0.00 \mathrm{c}$ & $6.16 \pm 0.78 \mathrm{~d}$ & $14.18 \pm 1.35 \mathrm{~d}$ \\
\hline ES & $0.00 \pm 0.00 \mathrm{c}$ & $3.08 \pm 0.61 \mathrm{de}$ & $8.63 \pm 0.78 \mathrm{e}$ \\
\hline FIL & $0.00 \pm 0.00 \mathrm{c}$ & $0.00 \pm 0.00 \mathrm{e}$ & $32.46 \pm 0.78 \mathrm{f}$ \\
\hline SIL & $9.19 \pm 1.60 \mathrm{~b}$ & $18.51 \pm 1.35 \mathrm{c}$ & $50.61 \pm 1.23 \mathrm{c}$ \\
\hline TIL & $14.81 \pm 1.35 \mathrm{a}$ & $35.79 \pm 1.23 \mathrm{a}$ & $43.82 \pm 1.13 \mathrm{~b}$ \\
\hline PS & $11.00 \pm 1.29 \mathrm{ab}$ & $26.53 \pm 1.13 \mathrm{~b}$ & \\
\hline
\end{tabular}

Table2. Effect of different concentrations $\left(1 \times 10^{2}, 1 \times 10^{4}\right.$ and $1 \times 10^{6} \mathrm{CFU} / \mathrm{mL}$ of Xanthomonas axanopodis via different method of inoculation (Intact leave (IL), Mechanical Injury (MI), Egg Stage (ES), $1^{\text {st }}$ instar larvae (FIL), $2^{\text {nd }}$ instar larvae (SIL), $3^{\text {rd }}$ Instar larvae (TIL), and pupal stage (PS) ) on disease incidence (\%) of citrus canker at 8 day interval

\begin{tabular}{cccc}
\hline Stage & $1 \times 10^{2}$ & $1 \times 10^{4}$ & $1 \times 10^{6}$ \\
\hline IL & $0.00 \pm 0.00 \mathrm{~d}$ & $5.55 \pm 0.82 \mathrm{~d}$ & $9.25 \pm 0.82 \mathrm{~d}$ \\
\hline MI & $4.31 \pm 1.13 \mathrm{~d}$ & $11.72 \pm 1.15 \mathrm{c}$ & $27.77 \pm 1.26 \mathrm{c}$ \\
\hline ES & $3.08 \pm 0.61 \mathrm{~d}$ & $14.81 \pm 1.35 \mathrm{c}$ & $26.53 \pm 1.14 \mathrm{c}$ \\
\hline FIL & $1.85 \pm 0.82 \mathrm{~d}$ & $11.10 \pm 1.36 \mathrm{~cd}$ & $23.34 \pm 1.19 \mathrm{c}$ \\
\hline SIL & $20.36 \pm 1.58 \mathrm{c}$ & $35.79 \pm 1.23 \mathrm{~b}$ & $53.69 \pm 1.58 \mathrm{~b}$ \\
\hline TIL & $32.71 \pm 1.13 \mathrm{a}$ & $49.37 \pm 1.24 \mathrm{a}$ & $68.51 \pm 1.59 \mathrm{a}$ \\
\hline PS & $27.15 \pm 1.23 \mathrm{~b}$ & $43.82 \pm 1.48 \mathrm{a}$ & $59.25 \pm 2.13 \mathrm{~b}$
\end{tabular}

Table3. Effect of different concentrations $\left(1 \times 10^{2}, 1 \times 10^{4}\right.$ and $\left.1 \times 10^{6} \mathrm{CFU} / \mathrm{mL}\right)$ of Xanthomonas axanopodis via different method of inoculation (Intact leave (IL), Mechanical Injury (MI), Egg Stage (ES), $1^{\text {st }}$ instar larvae (FIL), $2^{\text {nd }}$ instar larvae (SIL), $3^{\text {rd }}$ Instar larvae (TIL), and pupal stage (PS) on disease incidence (\%) of citrus canker at 12 day interval

\begin{tabular}{cccc}
\hline Stage & $1 \times 10^{2}$ & $1 \times 10^{4}$ & $1 \times 10^{6}$ \\
\hline IL & $1.85 \pm 0.83 \mathrm{e}$ & $7.40 \pm 1.65 \mathrm{f}$ & $15.42 \pm 1.13 \mathrm{f}$ \\
\hline MI & $9.87 \pm 1.23 \mathrm{~d}$ & $18.51 \pm 1.35 \mathrm{de}$ & $41.35 \pm 1.14 \mathrm{~d}$ \\
\hline ES & $10.48 \pm 1.49 \mathrm{~d}$ & $23.45 \pm 1.24 \mathrm{~d}$ & $31.47 \pm 0.82 \mathrm{e}$ \\
\hline FIL & $5.50 \pm 1.26 \mathrm{de}$ & $16.04 \pm 1.23 \mathrm{e}$ & $62.34 \pm 1.48 \mathrm{c}$ \\
\hline SIL & $29.00 \pm 1.76 \mathrm{c}$ & $46.90 \pm 1.25 \mathrm{c}$ & $81.47 \pm 2.13 \mathrm{a}$ \\
\hline TIL & $43.81 \pm 1.14 \mathrm{a}$ & $64.81 \pm 1.58 \mathrm{a}$ & $71.60 \pm 1.83 \mathrm{~b}$ \\
\hline PS & $36.41 \pm 1.48 \mathrm{~b}$ & $55.56 \pm 1.36 \mathrm{~b}$ & \\
\hline
\end{tabular}


Table4. Effect of different concentrations $\left(1 \times 10^{2}, 1 \times 10^{4}\right.$ and $\left.1 \times 10^{6} \mathrm{CFU} / \mathrm{mL}\right)$ of Xanthomonas axanopodis via different method of inoculation (Intact leave (IL), Mechanical Injury (MI), Egg Stage (ES), $1^{\text {st }}$ instar larvae (FIL), $2^{\text {nd }}$ instar larvae (SIL), $3^{\text {rd }}$ Instar larvae (TIL), and pupal stage (PS) on disease incidence (\%) of citrus canker at 16 day interval

\begin{tabular}{cccc}
\hline Stage & $1 \times 10^{2}$ & $1 \times 10^{4}$ & $1 \times 10^{6}$ \\
\hline IL & $5.55 \pm 0.82 \mathrm{~d}$ & $13.57 \pm 0.78 \mathrm{f}$ & $18.51 \pm 1.35 \mathrm{~d}$ \\
\hline MI & $12.95 \pm 1.26 \mathrm{~cd}$ & $32.71 \pm 1.14 \mathrm{~d}$ & $41.97 \pm 1.24 \mathrm{c}$ \\
\hline ES & $19.13 \pm 1.48 \mathrm{c}$ & $36.41 \pm 1.13 \mathrm{~d}$ & $48.14 \pm 1.35 \mathrm{c}$ \\
\hline FIL & $12.34 \pm 1.23 \mathrm{~cd}$ & $25.92 \pm 1.35 \mathrm{e}$ & $78.39 \pm 1.36 \mathrm{c}$ \\
\hline SIL & $45.05 \pm 1.13 \mathrm{~b}$ & $64.19 \pm 1.83 \mathrm{c}$ & $93.20 \pm 2.22 \mathrm{a}$ \\
\hline TIL & $61.72 \pm 1.83 \mathrm{a}$ & $85.18 \pm 1.91 \mathrm{a}$ & $84.56 \pm 1.77 \mathrm{~b}$ \\
\hline PS & $58.17 \pm 2.88 \mathrm{a}$ & $76.53 \pm 1.24 \mathrm{~b}$ &
\end{tabular}

Table5. Effect of different concentrations $\left(1 \times 10^{2}, 1 \times 10^{4}\right.$ and $\left.1 \times 10^{6} \mathrm{CFU} / \mathrm{mL}\right)$ of Xanthomonas axanopodis via different method of inoculation (Intact leave (IL), Mechanical Injury (MI), Egg Stage (ES), $1^{\text {st }}$ instar larvae (FIL), $2^{\text {nd }}$ instar larvae (SIL), $3^{\text {rd }}$ Instar larvae (TIL), and pupal stage (PS) on disease incidence (\%) of citrus canker at 20 day interval

\begin{tabular}{cccc}
\hline Stage & $1 \times 10^{2}$ & $1 \times 10^{4}$ & $1 \times 10^{6}$ \\
\hline IL & $8.01 \pm 0.61 \mathrm{e}$ & $17.27 \pm 1.24 \mathrm{e}$ & $24.69 \pm 1.24 \mathrm{e}$ \\
\hline MI & $19.74 \pm 1.25 \mathrm{~d}$ & $41.35 \pm 1.13 \mathrm{c}$ & $53.70 \pm 1.26 \mathrm{c}$ \\
\hline ES & $27.15 \pm 1.23 \mathrm{c}$ & $42.59 \pm 1.59 \mathrm{c}$ & $55.56 \pm 1.35 \mathrm{c}$ \\
\hline FIL & $16.67 \pm 1.26 \mathrm{~d}$ & $33.32 \pm 1.35 \mathrm{~d}$ & $47.53 \pm 1.13 \mathrm{~d}$ \\
\hline SIL & $56.16 \pm 1.76 \mathrm{~b}$ & $75.92 \pm 1.58 \mathrm{~b}$ & $94.45 \pm 1.58 \mathrm{~b}$ \\
\hline TIL & $70.36 \pm 1.35 \mathrm{a}$ & $92.58 \pm 2.13 \mathrm{a}$ & $100.00 \pm 0.00 \mathrm{a}$ \\
\hline PS & $61.10 \pm 1.58 \mathrm{~b}$ & $87.03 \pm 1.58 \mathrm{a}$ & $100.00 \pm 0.00 \mathrm{a}$ \\
\hline DISCUSSION & & the disease incidence associated with inst
\end{tabular}

\section{DISCUSSION}

The disease incidence was observed to be directly proportional to concentrations, as incidence increase with increase the concentration. We investigated the different types of pathogen\ inoculation, and also checked the effect of different life stages of leafminer on disease occurrence at different concentrations and different exposure interval. We observed the direct correlation between concentration and disease occurrence. The similar results were also observed by Jesus Junior et al. (2006) and Christiano et al. (2007) that Xac inoculation at low concentration resulted reduce efficacy of pathogen in infection process. Our findings are in line with the observation of Graham et al. (2004) that disease incidence was found positively correlation with increase the inoculums concentrations. During current study infection started with a concentration of $10^{2} \mathrm{CFU} / \mathrm{mL}$ among all the inoculations methods and these results were also agreed with interpretations of Gottwald and Graham (1992), who reported that Xac infection may result from a few bacterial cells injected in sub-stomatal chamber. Approximately $11 \%$ increase in infection occurred when plant infested by different developmental stages of CLM as compared to mechanically inoculated leaf (Chagas et al., 2001). Some studies have not been clearly explained the disease incidence associated with insect pest (Graham et al., 2004). Minimum concentration required for infection with pathogen depending upon the damage status of leaf. During present study at $10^{2} \mathrm{CFU} / \mathrm{mL}$ third instar larvae, pupae and second instar larvae caused (70, 61 and $56 \%$ ) as compared to egg stage, mechanical injury and intact leave $(27,19$ and 8\%) incidence and these were similar to finding were given by Christiano et al. (2007). In case rt45rof mechanically wounding and CLM injuries (at different stages) a concentration of $10^{2}$ $\mathrm{CFU} / \mathrm{mL}$ required while $10^{4} \mathrm{CFU} / \mathrm{mL}$ in case of intact leaves, which similar to the results of Goto (1992). Belasque et al. (2005) also reported that maximum infection was achieved when leaves were infected with larvae and pupae stages. Maximum leaf injury occurred due to $3^{\text {rd }}$ instar larval and pupal infestation followed the disease incidence and severity, these similar findings were observed by Christiano et al., (2007) at low inoculum concentration $\left(10^{1} \mathrm{CFU} / \mathrm{mL}\right)$. The reason behind the high infection during the $3^{\text {rd }}$ and $2^{\text {nd }}$ instar larvae were exposed to mesophyll cell during the feeding process. The larger area feed by $3 \mathrm{rd}$ and $2^{\text {nd }}$ instar larvae more galleries were produced which ultimately result the spread of Xac and precede the infection. The low infection during the egg stage and $1^{\text {st }}$ instar due to the restriction of $1^{\text {st }}$ instar near the mid vein and while 
sessile behavior of eggs restricted the infection process. In case of intact leaves, the lowest infection occurs because the Xac only enter into the plant leaves through stomata without any mean of transmission (Chagas et al., 2001).

\section{CONCLUSION}

Based on the results reported it was concluded that in order to manage the disease occurrence more attention should be given to the knowledge of the biology and ecology of parasitoid species.

\section{REFERENCES}

Ba-Angood., S. A. S. 1977. A contribution to the biology and occurrence of the citrus leafminer, Phyllocnistis citrella Stainton (Lepidoptera: Gracillariidae) in the Sudan. Journal of Applied Entomology, 83: 106-111.

Belasque, J., A. L. Parra-Pedrazzoli, J. Rodrigues Neto, P. T. Yamamoto, M. C. M. Chagas, J. R. P. Parra, B. T. Vinyard and J. S. Hartung. 2005. Adult Citrus Leafminers (Phyllocnistis citrella) Are Not Efficient Vectors for Xanthomonas axonopodis pv. citri. Plant Disease, 89: 590-594.

Bradbury, J. F. 1986. Guide to plant pathogenic bacteria. CAB international.

Chagas, M. C. M. and J. R. P. Parra. 2000. Phyllocnistis citrella Stainton (Lepidoptera: Gracillariidae): Influence of three temperatures on biology and ability. Annals of the Entomological Society of Brazil, 29: 227-235.

Chagas, M. C. M., J. R. P. Parra, T. Namekata, J. S. Hartung and P. T. Yamamoto. 2001. Phyllocnistis citrella Stainton (Lepidoptera: Gracillariidae) and its relationship with the citrus canker bacterium Xanthomonas axonopodis pv citri in Brazil. Neotropical Entomology, 30: 55-59.

Christiano, R. S. C., M. Dalla Pria, W. C. Jesus Junior, J. R. P. Parra, L. Amorim and A. Bergamin Filho. 2007. Effect of citrus leafminer damage, mechanical damage and inoculum concentration on severity of symptoms of Asiatic citrus canker in Tahiti lime. Crop Protection, 26: 59-65.

Davis, D. R., W. De Prins and J. De Prins. 2006. World Catalogue of Insects, Volume 6, Gracillariidae (Lepidoptera). Annals of the Entomological Society of America, 99: 186-187.

Diez, P. A., J. E. Peña and P. Fidalgo. 2006. Population dynamics of Phyllocnistis citrella (lepidoptera: gracillariidae) and its parasitoids in Tafí Viejo,
Tucumán, Argentina. Florida Entomologist, 89: 328-335.

Goto, M., 1992. Citrus Canker. In: Kumar, J., H. S. Chaube, U. S. Singh and A. N. Mukhopadhyay, (eds.), Plant Diseases of International Importance. Prentice Hall, Englewood Cliffs. pp. 250-269.

Gottwald, T. R. 1992. A Device for Precise and Nondisruptive Stomatal Inoculation of Leaf Tissue with Bacterial Pathogens. Phytopathology, 82: 930.

Gottwald, T. R., G. Hughes, J. H. Graham, X. Sun and T. Riley. 2001. The Citrus Canker Epidemic in Florida: The Scientific Basis of Regulatory Eradication Policy for an Invasive Species. Phytopathology, 91: 30-34.

Gottwald, T., J. Graham and T. Schubert. 1997. An epidemiological analysis of the spread of citrus canker in urban Miami, Florida, and synergistic interaction with the Asian citrus leafminer. Fruits, 6: 383-390.

Graham, J. H., T. R. Gottwald, J. Cubero and D. S. Achor. 2004. Xanthomonas axonopodis pv. citri: factors affecting successful eradication of citrus canker. Molecular Plant Pathology, 5: 1-15.

Graham, J., T. Gottwald, H. Browning and D. Achor. 1996. Citrus leafminer exacerbated the outbreak of Asiatic citrus canker in South Florida. Proceedings, International Meeting: Managing the Citrus Leafminer. pp. 22-25.

Jesus Junior, W. C., J. Belasque Júnior, L. Amorim, R. S. C. Christiano, J. R. P. Parra and A. Bergamin Filho. 2006. Injuries caused by citrus leafminer (Phyllocnistis citrella) exacerbate citrus canker (Xanthomonas axonopodis pv. citri) infection. Fitopatologia Brasileira, 31: 277-283.

Liu, Y., E. Heying and S. A. Tanumihardjo. 2012. History, Global Distribution, and Nutritional Importance of Citrus Fruits. Comprehensive Reviews in Food Science and Food Safety, 11: 530-545.

PeñA, J. E., R. Duncan and H. Browning. 1996. Seasonal Abundance of Phyllocnistis citrella (Lepidoptera: Gracillariidae) and its Parasitoids South Florida Citrus. Environmental Entomology, 25: 698-702.

Pruvost, O., C. Vernière, J. Hartung, T. Gottwald and H. Quetelard. 1997. Towards an improvement of citrus canker control in Reunion Island. Fruits, 6: 375-382.

Sharif, M., N. Akmal and S. Taj. 2009. Financial viability 
for investing in citrus cultivation in Punjab, Pakistan. Journal of Agricultural Research (03681157), 47.

Sohi, G. S. and M. S. Sandhu. 1968. Relationship between citrus leafminer (Phyllocnistis citrella Stainton) injury and citrus canker (Xanthomonas citri (Hasse) Dowson) incidence on citrus leaves. Journal of Research Punjab Agriculture University. 5: 66-69.

Sokal, R. and F. Rohlf. 1995. Biometry: The Principles and Practice of Statistics in Biological Research. 3d Edition. WH Freeman and Co., New York, USA.

Timmer, L. W. 2000. Inoculum production and epiphytic survival of Xanthomonas campestris pv. citri.
(Abstr.) In: Proceedings of the International Citrus Canker Research Workshop, Ft. Pierce FL, June, 20-22. Division of Plant Industry, Florida Department of Agriculture and Consumer Services. USA.

Urbaneja, A., E. Llácer, A. Garrido and J.-A. Jacas. 2003. Interspecific competition between two ectoparasitoids of Phyllocnistis citrella (Lepidoptera: Gracillariidae): Cirrospilus brevis and the exotic Quadrastichus sp. (Hymenoptera: Eulophidae). Biological Control, 28: 243-250.

Waller, J.M., J.M. Lenne, S.J. Waller. 2002. Plant Pathologist Pocketbook. 3rd Edition. CABI Publishing, New York, pp. 27.

\section{Contribution of Authors:}

Amna Riasat $\quad$ : Conduct research and write manuscript.

Muhammad U. Ghazanfar $\quad$ : Supervisor of research and review manuscript.

Waqas Raza $\quad:$ Apply statistics and help in conducting research. 